\title{
Satisfaction and Loyalty of Inpatients in International Hospital at Jakarta, Tangerang and Bekasi
}

\author{
Kartono, Farida Jasfar, HamdyHady \\ willy.arafah@gmail.com
}

\begin{abstract}
The purpose of this study is to examine and analyze the influence of doctor performance, therapeutic, nurse performance and patient trust towards patient satisfaction and patient loyalty in inpatient at international hospital at Jakarta, tangerang and Bekasi. This study also has the purpose to examine the influence of patient satisfaction towards patient loyalty. The research design used survey method with data collection through a questionnaire. Sampleof 400 inpatients was conducted by using non probability sampling. Analytical technique used in testing the hypothesis is Structural Equation Model (SEM).The results provide evidence that patient loyalty is most influenced by patient trust. Patient loyalty is also influenced by patient satisfaction, doctor performance and therapeutic. Patient satisfaction is influenced by patient trust, nurse performance and doctor performance. This model can give enrichment for patient loyalty reference, especially for inpatient.
\end{abstract}

Keywords: Doctor Performance, Therapeutic, Nurse Performance, Patient Trust, Patient Satisfaction And Patient Loyalty

\section{INTRODUCTION}

The ASEAN Economic Community which was implemented on 31 December 2015 is a continuation of the era of globalization that will bring changes in the field of life, including in the health sector. The ASEAN Economic Community brings millions of opportunities and challenges (Puja, 2016). Potential benefits can be in the form of the creation of broad employment opportunities in health care facilities, increasing the quality of health services and the level of public health and reducing poverty and socio-economic inequality (Anwar, 2016).

Improving health services is basically an investment of human resources to achieve a prosperous society (Khariza, 2015). The national health insurance program is a government program that aims to provide comprehensive health insurance for every Indonesian community in order to live a healthy, productive and prosperous life (SJSN Law, 2012). This program is part of the national social security system that is mandatory for all residents through the Health Social Security Organizing Body. The implementation of the national health insurance program by the Health Social Security Administering Agency began on January 1, 2014 (SJSN Law, 2012) (Saputra etal, 2015). In the development of the implementation of the National Health Insurance program, a number of problems were complained by patients related to the services provided, including a decrease in the quality of services. This happens because of an increase in the number of patients that occur because anyone can now become a participant in the National Health Insurance (Khariza, 2015).

Indonesia Services Dialogue notes that Indonesians who go abroad for treatment have increased in the past 10 years. In 2006 there were 350,000 patients, while in 2015 it increased to 600,000 patients (Online Digest, 12 June 2017, Tribunnews.com, 25 Jan 2017). Expenditure of Indonesian patients seeking treatment abroad in 2015 reached 1.4 billion US dollars, equivalent to Rp 18.2 trillion (Liputan6.com, March 10, 2016). Ministry of Health data states that 12,000 Indonesians seek treatment in Malaysia each year. Mentioned in Singapore's National Health Care Group International Business Dev Unit (NHG-IBDU) data, 50\% of international patients in Singapore are Indonesian. 
Satisfaction and Loyalty of Inpatients in International Hospital at Jakarta, Tangerang and Bekasi

Based on its accreditation, hospitals can be classified into hospitals with KARS accreditation (Hospital Accreditation Committee) and hospitals with accreditation JCI (Join International Commission), which is also often called a hospital with international accreditation. In February 2018 there were twenty-six hospitals in Indonesia that received JCI certification, with details of sixteen hospitals in Indonesia that received hospital program certification. Nine hospitals in Indonesia received education hospital program certification (Academic Medical Center Hospital ) and one hospital for outpatient care only. The sixteen hospitals that received hospital program certification are:

Table1. Hospital with Join International Commision (JCI) Accreditation

\begin{tabular}{|c|l|l|l|}
\hline No & \multicolumn{1}{|c|}{ Hospital } & \multicolumn{1}{c|}{ Location } & \multicolumn{1}{c|}{ Accreditation } \\
\hline 1 & RS Awal Bros batam & Batam & 02 Juli 2014 \\
\hline 2 & RS Awal Bros Bekasi & Bekasi & 18 April 2014 \\
\hline 3 & RS Awal Bros Pekanbaru & Pekanbaru & 28 Juni 2014 \\
\hline 4 & RS Awal Bros Tangerang & Tangerang & 25 April 2014 \\
\hline 5 & RS Eka & Tangerang & 11 Desember 2010 \\
\hline 6 & RS EkaPekanbaru & Pekanbaru & 01 Maret 2014 \\
\hline 7 & RS Fatmawati & Jakarta & 14 Desember 2013 \\
\hline 8 & RS JantungNasionalHarapan Kita & Jakarta & 28 Mei 2016 \\
\hline 9 & RS Pondok Indah - Puri Indah & Jakarta & 16 Maret 2013 \\
\hline 10 & RS Pondok Indah - Pondok Indah & Jakarta & 08 April 2017 \\
\hline 11 & RS Premier Bintaro & Tangerang & 15 Januari 2011 \\
\hline 12 & RS Premier Surabaya & Surabaya & 06 Maret 2013 \\
\hline 13 & RS PAD GatotSubroto & Jakarta & 04 Juli 2014 \\
\hline 14 & RS Siloam Bali & Bali & 06 September 2017 \\
\hline 15 & RS Siloam KebonJeruk & Jakarta & 13 Agustus 2016 \\
\hline 16 & RS Siloam Lippo Village & Banten & 19 September 2007 \\
\hline
\end{tabular}

Source: https://www.jointcommissioninternational.org, February 19,2018

\section{THEORETICAL FRAMEWORK}

\section{Patient Trust}

According to Baidya et al. (2013) interest in doctor-patient trust has increased dramatically since 1979, when Russell Caterinicchio published the first study entitled "Testing the Interpersonal Belief Pathway Model in the Relationship of Medicine to Doctors". Other researchers have emphasized the affective nature of trust, identifying patient trust as a feeling of confidence or convincing confidence in the doctor and the doctor's intentions (Lien et al, 2014).

Trust is the acceptance of a vulnerable situation, where vulnerable parties believe that the party who is trusted will act in the best interests of the parties who believe (Thom et al., 2004). Evidence from qualitative studies shows that patient trust is a state, not a trait, and therefore can change (Thom et al., 2004).Increased commercialization of medical practices erodes layman's belief in the medical profession (Baidya et al., 2013). Understanding trust can provide a vision of how health law and the medical market must function (Baidya et al., 2013).

According to Zineldin (2015) medical errors are the most preventable factor to prevent patients from harm and hundreds of thousands of people die and millions more are injured each year due to lack of proper care and lack 
of other treatments. The annual cost of medical errors in America is estimated at around \$17.1 billion in 2008 (Van Den Bos et al., 2011). Top management support is very important to improve the quality of health services (Zineldin, 2015).The influence of trust on quality and satisfaction is highlighted by many studies and authors (Chang et al., 2013) and should not be ignored.

Patients are now more informed and or more willing to participate in decisions regarding their own care (Rowe and Calnan, 2006). Patients at the referral level hospital also need to get service quality and satisfaction (Naik J.R.K. et al, 2014). Interpersonal trust can be used to define patient trust and that the core concept of patient trust is acceptance of a vulnerable situation where the patient believes that the doctor will act in the best interest (Van D.A., 2013).Consumer trust in service providers can help reduce their cognitive risk and insecurity and thus enable maintenance of long-term relationships (Rowe and Calnan, 2006). When a patient trusts a doctor, he or she will tend to give positive words of mouth (Lien et al., 2014).

Cultural identity theory currently argues that individuals usually identify more than one cultural group, while research on health service interaction shows that it can make a higher need for some health measures than monocultural individuals (Simonds, 2013). Patient trust refers to the patient's belief that health care providers will act as expected (Yarmen et al, 2016).In the health industry, service quality positively affects patient trust in hospitals (Ce et al, 2014). Therefore, the influence of trust on service quality and customer satisfaction cannot be ignored in interpersonal service-based meetings (Chang et al, 2013).

\section{Treatment}

Doctor care contribute patient satisfaction and loyalty. It involves the process of diagnosing the ailment and providing medical treatment (Chahal, Mehta, 2013). Medical quality is a determinant of inpatient satisfaction (Yipeng et al, 2016). Higher patient satisfaction makes patient more comply with doctor's recommended treatment (Batbaatar et al (2017).

\section{Doctor Performance}

It is interesting to see that the study revealed some differences regarding the impact of the performance of doctors and nurses related to patient safety, trust and satisfaction (Zineldin 2015). While the first and most decisive performance of doctor from the patient's perspective is trust and then security (Zineldin 2015). There is a positive relationship between doctor performance and patient trust and satisfaction. The strongest determinant of outpatient satisfaction was satisfaction with doctor communication (Yipeng et al, 2016). Doctor care contribute patient satisfaction and loyalty. It involves the process of diagnosing the ailment and providing medical treatment (Chahal, Mehta, 2013).

\section{Nurse Performance}

The most decisive performance of nurses is satisfaction and then trust. It seems that patients need different important elements from doctors and nurses. They want trust in doctors and satisfaction with nurses (Zineldin 2015). This is very logical because the patient is very aware that the doctor is able to diagnose the disease, prescribe the medicine or perform surgery (Sumaedi, 2016). Nursing care contribute patient satisfaction and loyalty (Chahal, Mehta, 2013). Nurse performance is a determinant of inpatient satisfaction (Yipeng et al, 2016).

\section{Patient Satisfaction}

Patient-centered care is defined as providing care that respects and answers individual patient preferences, needs and values and ensures patient values determine all clinical decisions (Crosier et al., 2012).Patient satisfaction can be measured by qualitative or quantitative methods (Shirley et al., 2016). Smaller practices, related to higher patient satisfaction in terms of access and continuity of care compared to larger practices (Glenngard, 2012).The definition of customer satisfaction can be drawn as a feeling of pleasure or dislike of a consumer after evaluating the performance of an item or service with the expectations included when buying 
or using the item or service (Hawthorne et al, 2014). Patient satisfaction is achieved through the incorporation of good behavioral factors from doctors (Bharamanaikar and Kadadi, 2016).

Specifically, patient satisfaction is a measure of patient attitudes toward doctors, medical care and health care systems (Chahal and Mehta, 2013). Complementary factors that affect inpatient and outpatient care separately and analyze their differences can provide more information for the health system (Yipeng, 2016). Patient satisfaction research shows that along with doctor's medical skills, qualities such as listening and interpersonal skills are rated highly (Naidu, 2009).

\section{Patient Loyalty}

According to Yarmen et al (2016) patient loyalty is one of the topics that developed in the health services literature. patient loyalty is expected to provide a competitive advantage for health care institutions (Chang et al., 2013). Loyalty will be a key factor in the success of health care providers (Yarmen et al, 2016).Empirical studies have investigated the simultaneous effects of risk, image, subjective norms, and perceived trust in patient loyalty (Yarmen et al, 2016).

Service providers with loyal customers will get many significant benefits, such as increasing market share, reducing marketing costs to attract new customers and increase revenue and profits (Chang et al., 2013). Loyalty is defined as a customer commitment to keep using certain service providers even though he has the opportunity and resources to switch to other providers (Chang et al., 2013). Thus, patient loyalty represents the patient's commitment to reuse health care institutions and recommend them to others. Most of them propose service quality and satisfaction to be a driver of patient loyalty (Kessler and Milod, 2011).

According to Sumaedi et al (2014) patient loyalty has been identified as a major factor in business success. A health service institution that can develop and maintain the loyalty of patients will get many benefits, such as increased income and positive word-mouth communication (Chang Et al., 2013). Health care services have become a competitive sector (Chang et al., 2013). Patient loyalty is influenced by trust and satisfaction (Panchapakesan et al, 2015).

Patient loyalty is also influenced by relationship satisfaction and patient trust in doctors (Astuti and Nagase, 2014). Chang et al. (2013) suggested that customer satisfaction is not enough to explain patient loyalty. In Indonesia, satisfaction does not affect patient loyalty (Sumaedi, 2016).In addition, the model testing also provides new insights to understand the relationship between dimensions of patient satisfaction and loyalty (Lei and Jolibert, 2012).

\section{CONCEPTUAL FRAMEWORK FOR RESEARCH AND RESEARCH HyPOTHESIS}

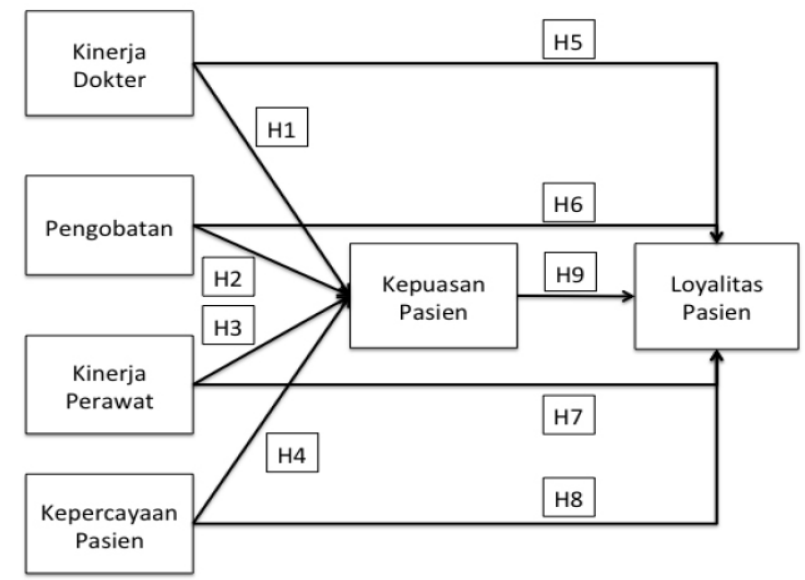

Based on theories related to the variables of physician performance, treatment, nurse performance, inpatient trust and inpatient satisfaction and inpatient loyalty, the following research hypotheses were compiled. 
Satisfaction and Loyalty of Inpatients in International Hospital at Jakarta, Tangerang and Bekasi

\section{H1: There is an Influence of Doctor Performance on Inpatient Satisfaction}

Zineldin (2015) conducted a study to determine the determinants of patient satisfaction. Van and Dulewicz (2014) conducted a study on the relationship of patient satisfaction with trust, practice orientation and performance. This is supported also by subsequent research by Van and Dulewicz (2015). The important thing in the doctor's performance according to the patient is the doctor's interpersonal skills and expertise (Batbaatar et al.,2016). Doctor's performance is an aspect that determines patient satisfaction(Chahal and Mehta, 2013). This involves the process of determining the diagnosis and providing adequate treatment. The main factor of doctor's performance is friendly behavior (Chahal and Mehta, 2013).

\section{H2: There is an Influence of Treatment on Inpatient Satisfaction}

Chahal and Mehta (2013) state that patient satisfaction is a multi-dimensional construct, including treatment therein. Treatment, including equipment and technology owned by health care providers, has a significant effect on patient satisfaction (Naidu A., 2009). The relationship between patient satisfaction and treatment is determined primarily on the similarity of patient and physician perceptions of the results to be achieved with treatment. Treatment goals that are well communicated can improve patient satisfaction (Crosier et al., 2012). Yi Peng et al (2016) found in their study that one of the determinants of outpatient satisfaction was the physician's communication about the treatment regimen and one of the determinants of satisfaction of inpatients was the quality of treatment or equipment and technology from health care providers.

\section{H3: There is an Influence of Nurse Performance on Inpatient Satisfaction}

Zineldin (2015) states that patients relate more to their satisfaction with nurses 'performance than doctors' performance.Likewise with the study of Batbaatar et al (2017), where the factors of doctors and nurses are the two main things in determining patient satisfaction. Patient satisfaction is a multi-dimensional construct where care by nurses is included (Chahal and Mehta, 2013)

\section{H4: There is an Influence of Inpatient Trust on Inpatient Satisfaction}

Trust in doctors is associated with patient satisfaction (Tang, 2012). The higher the patient's trust, the higher the level of satisfaction (Baidya et al., 2014). Patient trust positively affects patient satisfaction (Chang et al., 2013). Patient trust in health services includes trust in medical service providers, trust in doctors, doctor's prescriptions and recommended medical examinations (Zineldin, 2015). This patient's trust provides a positive relationship with patient satisfaction (Tang, 2012). Patient trust also results in patient satisfaction (Van and Dulewicz, 2014 and Van and Dulewicz, 2015).

\section{H5: There is an Influence of Doctor Performance on Inpatient Loyalty}

The performance of doctors influences and significantly contributes to patient satisfaction and is also an important intermediary factor between patient satisfaction and patient loyalty (Chahal and Mehta, 2013). A good doctor's performance causes patients to recommend doctors to other parties (Van and Dulewicz, 2015).

\section{H6: There is an Influence of Treatment on Inpatient Loyalty}

Chahal and Mehta (2013) state that treatment, including equipment and technology owned by health care providers, has a significant effect on patient satisfaction and patient loyalty. The relationship between patient loyalty and treatment is determined primarily in the results achieved with treatment. Treatment goals that are well communicated can improve patient satisfaction (Crosier et al., 2012).

\section{H7: There is an Influence of Nurse Performance on Inpatient Loyalty}

Patient loyalty is influenced by many factors such as trust, satisfaction and performance of health workers, where nurses are included (Ramli and Sjahruddin, 2015). Nurse performance is a factor that supports patient 
satisfaction and indirectly provides patient loyalty (Chahal and Mehta, 2013). The success of maintaining patient loyalty cannot be separated from the role of existing health care human resources, including nurses (Sumaedi et al., 2015)

\section{H8: There is an Influence of Inpatient Trust on Inpatient Loyalty}

The success of the hospital keeps patient loyalty influenced by patient trust (Ramli and Sjahruddin, 2015). Sumaedi S et al. (2015) conducted a study to determine the effect of subjective norms, behavioral perceptions and patient beliefs on patient loyalty, where found subjective norms and patient beliefs influence patient loyalty.

\section{H9: There is an Influence of Inpatient Satisfaction on Inpatient Loyalty}

Patient satisfaction provides a significant influence on patient loyalty (Chang et al., 2013). The success of maintaining patient loyalty is influenced by several factors, such as patient trust, patient satisfaction (Ramli and Sjahruddin, 2015).

\section{RESEARCH METHODS}

According to Sekaran and Bougie (2013) the research design is all the processes carried out in planning and conducting research. The research process starts from the interpretation, selection and formulation of the problem until the formulation of the hypothesis and its relation to the existing theory and literature. The next process is the operational stage. In this study a sample survey of a population is used by using a questionnaire as a data collection tool and analyzing respondents as research subjects. The design for this type of research is to test hypotheses, including theories from the basis of the truth of the hypothesis being tested.

Variable measurements are carried out on independent variables: doctor's performance, treatment, nurse performance, patient trust, dependent variables: patient loyalty, and intermediate variables: patient satisfaction.

\section{Population, Sample and Data Collection Method}

The population of this study are patients who received health services at international public hospitals in Jakarta, Tangerang and Bekasi.The sample in this study uses a non probability sampling design. The sampling technique used in this study is Non Probability Sampling, and to determine the number of samples using Slovin. To get a sample, the quota method is used based on the number of inpatients in the international-level hospitals studied. The sample criteria used in this study were patients of international-standard hospitals in Jakarta, Tangerang or Bekasi who had been hospitalized in 2017 - 2018. Based on Slovin calculations obtained a sample of 400 .

Variables in this study patient loyalty as exogenous variables and physician performance, treatment and performance of nurses as well as patient trust as endogenous variables and patient satisfaction as intermediate variables. The respondent's attitude was measured using a Likert 5 scale.

Questionnaire designs are based primarily on multiple item measurement scales (Baker, 1991; Churchill, 1979), and all instruments developed using a five-point rating scale. To ensure adequate words for the questionnaire (Oppenhein, 1996), tests were conducted on thirty respondents and practical interviews, after modifications were made before the actual data collection.

\section{Data Analysis Method}

Data analysis used descriptive statistical analysis and analysis of Structural Equation Models (SEM). The reason for using SEM in this study is that SEM has the ability to estimate the relationships between variables that 
Satisfaction and Loyalty of Inpatients in International Hospital at Jakarta, Tangerang and Bekasi

are multiple and SEM has the ability to describe the pattern of relationships between latent constructs and manifest variables.

\section{RESULT}

Analysis of the respondent's profile is based on the data obtained in the first part of the questionnaire. Questionnaires were distributed to 400 patients who had been hospitalized in 2017 - 2018 at 11 international hospitals in Jakarta, Tangerang and Bekasi.

Table2. Patient Profile

\begin{tabular}{|c|c|c|}
\hline Patient Profile & $\mathbf{n}$ & $\%$ \\
\hline Class 3 & 98 & $25 \%$ \\
\hline Class 2 & 95 & $24 \%$ \\
\hline Class 1 & 110 & $28 \%$ \\
\hline VIP or above & 97 & $24 \%$ \\
\hline \multicolumn{3}{|l|}{ Cause of Hospitalization } \\
\hline Surgical & 127 & $32 \%$ \\
\hline Non surgical & 273 & $68 \%$ \\
\hline \multicolumn{3}{|l|}{ Length of Treatment } \\
\hline 1-3 days & 11 & $3 \%$ \\
\hline 4-6 days & 125 & $31 \%$ \\
\hline 7-9 days & 207 & $52 \%$ \\
\hline 10 days or more & 57 & $14 \%$ \\
\hline \multicolumn{3}{|l|}{ Gender } \\
\hline Man & 224 & $56 \%$ \\
\hline Woman & 176 & $44 \%$ \\
\hline \multicolumn{3}{|l|}{ Age } \\
\hline $17-45$ years & 121 & $30 \%$ \\
\hline 46-65 years & 183 & $46 \%$ \\
\hline 65 years above & 96 & $24 \%$ \\
\hline \multicolumn{3}{|l|}{ Education } \\
\hline Junior High School & 19 & $5 \%$ \\
\hline Senior High School & 135 & $34 \%$ \\
\hline Diploma & 38 & $10 \%$ \\
\hline S1 or above & 208 & $52 \%$ \\
\hline \multicolumn{3}{|l|}{ Marital Status } \\
\hline Unmarried & 34 & $9 \%$ \\
\hline Married & 273 & $68 \%$ \\
\hline Widower/widow & 93 & $23 \%$ \\
\hline \multicolumn{3}{|l|}{ Financing } \\
\hline Own Pocket & 84 & $21 \%$ \\
\hline Insurance non BPJS & 178 & $45 \%$ \\
\hline BPJS & 138 & $35 \%$ \\
\hline \multicolumn{3}{|l|}{ Income } \\
\hline 0-Rp5.000.000 & 101 & $25 \%$ \\
\hline Rp5.000.001 - Rp 10.000.000 & 98 & $25 \%$ \\
\hline$>\mathrm{Rp} 10.000 .000$ & 201 & $50 \%$ \\
\hline
\end{tabular}

Source: Data Analysis, 2018 
Respondent profiles based on inpatient class showed that respondents were treated in the third class $24.50 \%$, second class $23.75 \%$, first class $27.50 \%$ and VIP class or higher is $24.25 \%$. Causes of hospitalization shows that $31.75 \%$ of the causes were surgical and $68.25 \%$ of causes of hospitalization were non-surgical. Based on time or length of treatment shows that the most respondents treatment time is between 7-9 days at 51.75\%. Based on gender shows that $44 \%$ of respondents are women and $56 \%$ of respondents are men. Based on age shows that the age of most respondents is at the age of 46-65 years, which is $45.75 \%$. Based on education shows that most of inpatient at international hospital at Jakarta, tangerang and Bekasi were S1 or higher. Based on financing shows that most respondents use insurance as financing for care. The use of non-BPJS insurance is $44.50 \%$ and the use of BPJS insurance as care financing is 34.50\%. 50.25\% of respondents have income of more than Rp10,000,000.

Table3. Satisfaction and Loyalty Inpatient in Different Class

\begin{tabular}{|l|c|c|c|c|c|c|}
\hline Class & KD & PE & KP & KC & KA & LP \\
\hline Class 3 & 3.18 & 3.29 & 2.62 & 3.38 & 3.15 & 2.65 \\
\hline Class 2 & 3.34 & 3.46 & 3.07 & 3.63 & 3.41 & 2.78 \\
\hline Class 1 & 3.44 & 3.53 & 3.4 & 3.72 & 3.64 & 2.78 \\
\hline VIP or above & 3.82 & 3.73 & 3.84 & 3.91 & 3.87 & 3.02 \\
\hline
\end{tabular}

Source: Data Analysis, 2018

Where:

KD: Doctor Performance

PE: Treatment

KP: Nurse Performance

KC: Inpatients Trust

KA: Inpatients Satisfaction

LP: Inpatient Loyalty

The higher class of inpatient, the higher doctor performance, treatment, nurse performance and patient trust. This higher performance impact higher patient satisfaction and patient loyalty.

Table4. Satisfaction and Loyalty Inpatient in Different Financing

\begin{tabular}{|l|c|c|c|c|c|c|}
\hline Financing & KD & PE & KP & KC & KA & LP \\
\hline Self Financing & 3.54 & 3.58 & 3.38 & 3.68 & 3.61 & 2.75 \\
\hline Insurance nonBPJS & 3.52 & 3.53 & 3.38 & 3.70 & 3.58 & 2.73 \\
\hline BPJS & 3.28 & 3.43 & 2.96 & 3.60 & 3.39 & 2.95 \\
\hline
\end{tabular}

Source: Data Analysis, 2018

Self financing of inpatient has the highest doctor performance, treatment, nurse performance and give the highest impact to patient satisfaction. The BPJS financing has the lowest doctor performance, treatment, nurse performance and patient trust and give the lowest impact to patient satisfaction, but the patient loyalty is the highest.

\section{Hypothesis Testing Results}

The verification analysis in this study was conducted using a two-step approach, namely the measurement 
Satisfaction and Loyalty of Inpatients in International Hospital at Jakarta, Tangerang and Bekasi

model analysis, which is intended to see construct validity and reliability and structural model analysis, which is intended to see the relationship between constructs.

\section{Validity and Reliability Test}

Validity test can be seen from the processed data in the outer loading form of the research model used. All constructs from variables can be said to be valid if they have a minimum number of 0.40 .

Table5. Reliability Testfor the Variable

\begin{tabular}{|l|c|c|}
\hline \multicolumn{1}{|c|}{ Variabel } & Cronbach Alpha & Conclusion \\
\hline Doctor Performance & 0.890 & Reliable \\
\hline Treatment & 0.835 & Reliable \\
\hline Nurse Performance & 0.942 & Reliable \\
\hline Patient Trust & 0.927 & Reliable \\
\hline Patient Satisfaction & 0.915 & Reliable \\
\hline Patient Loyalty & 0.875 & Reliable \\
\hline
\end{tabular}

Source: Data Analysis SPSS 22, 2018

Reliability testing is done to measure whether all variable constructs have reliability for each test. A variable construct can be said to be reliable if it has a Cronbach's Alpha value and a Composite Reliability above 0.60 .

Based on the test, it can be concluded that the six variables of the study are valid. All coefisien correlation indicator is greater than Cronbach alpha 0.60, meaning all items statements serve as reliable.

\section{GOODNESS OF FIT TEST}

Based on the results of testing using the LISREL8.80 software, the model conformity index summary is obtained as follows, the test results show that the criteria used are absolute fit measures, incremental fit measures and parsimonious fit measures, the structural model proposed in this study has a good model suitability index on two criteria, namely incremental fit measures (NFI and CFI) and parsimonious fit measures (PNFI and PGFI). Thus, the analysis can be continued in the next analysis (Hair et al., 2010).

Table6. Confirmatory Factor Analysis Patient Loyalty

\begin{tabular}{|c|c|c|c|c|c|}
\hline Indikator & \begin{tabular}{|c|} 
Standardized Loading \\
Factor
\end{tabular} & $\begin{array}{c}\text { Error } \\
\text { Variance }\end{array}$ & $\begin{array}{c}\text { Std } \\
\text { Loading2 }\end{array}$ & $\begin{array}{l}\text { Construct } \\
\text { Reliability }\end{array}$ & $\begin{array}{l}\text { Variance } \\
\text { Extracted }\end{array}$ \\
\hline LP1 & 0.900 & 0.300 & 0.8100 & \multirow{7}{*}{0.884} & \multirow{7}{*}{0.537} \\
\hline LP2 & 0.940 & 0.220 & 0.8836 & & \\
\hline LP3 & 0.700 & 0.600 & 0.4900 & & \\
\hline LP4 & 0.870 & 0.340 & 0.7569 & & \\
\hline LP5 & 0.860 & 0.360 & 0.7396 & & \\
\hline LP6 & 0.550 & 0.800 & 0.3025 & & \\
\hline LP7 & 0.390 & 0.950 & 0.1521 & & \\
\hline ( $\sum$ Std Loading) & 5.210 & & & & \\
\hline ( $\sum$ Std Loading) 2 & 27.144 & & & & \\
\hline ( $\sum$ Std Loading2) & 4.1347 & & & & \\
\hline ( $\sum$ Error Variance) & 3.5700 & & & & \\
\hline
\end{tabular}

Source: Data Analysis LISREL \&MS.Excell, 2018 
Confirmatory Factor Analysis (CFA), which is a measurement model that models the relationship between latent (unobserved) variables and indicators that make up the variable. The relationship is reflective, namely the forming indicator is a reflection of the latent variable.

Based on the results of testing Confirmatory Factor Analysis for the variables of physician performance, treatment, nurse performance, patient trust, patient satisfaction and patient loyalty meet the requirements or fit as a measurement model.

\section{Full SEM Model}

The full SEM equation model with LISREL 8.80 obtained two models, namely the standard model and the $\mathrm{t}$-values model. Based on the model, an SEM Full Model measurement model is performed for each variable.

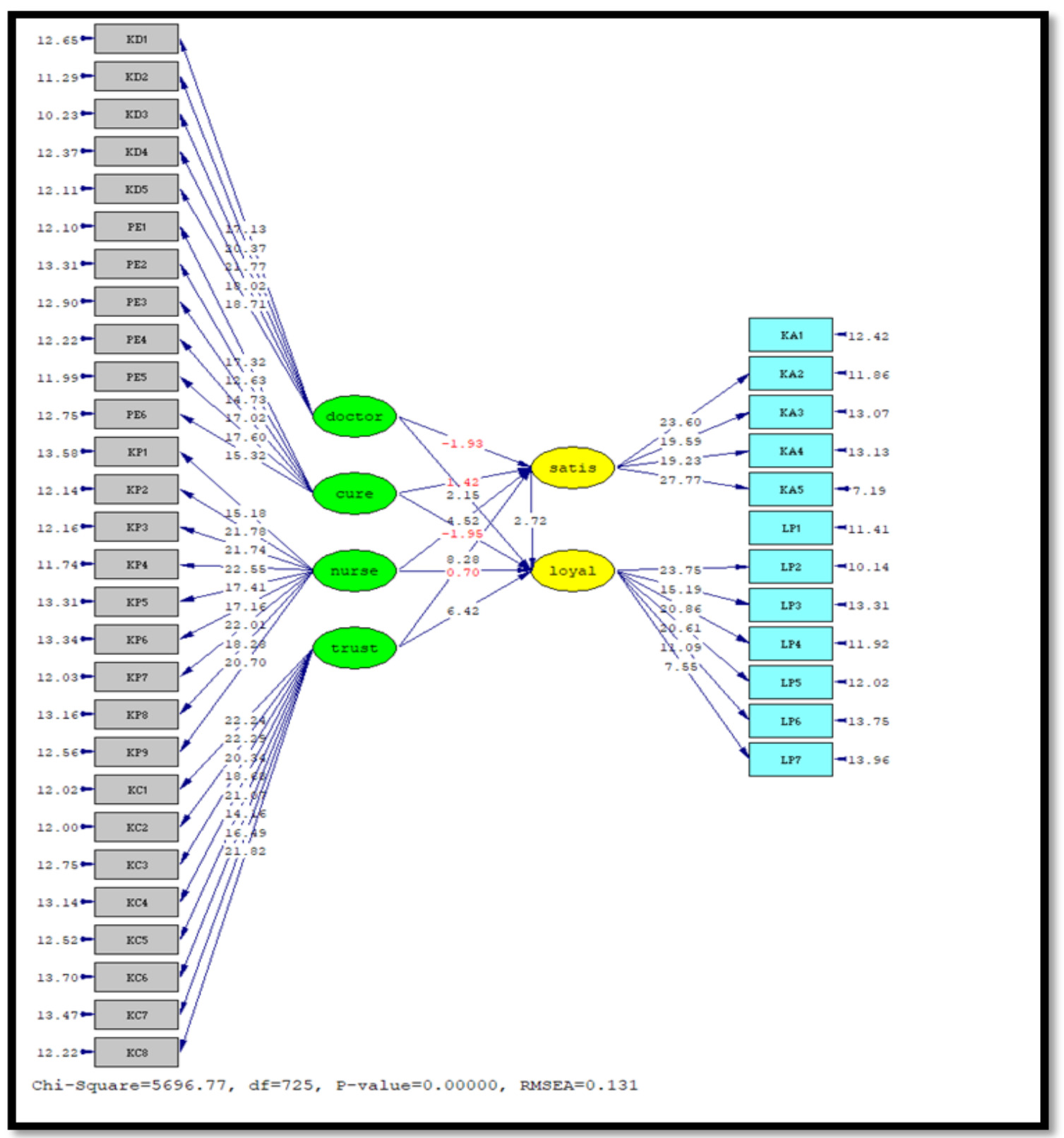

Source : LISREL 8.80, 2018 
Testing hypotheses about the effect of exogenous variables on physician performance, treatment, nurse performance and inpatient trust on inpatient satisfaction and the influence of exogenous variables on physician performance, treatment, nurse performance, inpatient trust and inpatient satisfaction on inpatient loyalty done using the Lisrel 8.80 program. The results obtained for structural equation models, in accordance with the proposed hypothesis are:

$\mathrm{KA}=-0.13^{*} \mathrm{KD}+0.13^{*} \mathrm{PE}+0.25^{*} \mathrm{KP}+0.66^{*} \mathrm{KC}$,

Errorvar. $=0.25, \mathrm{R}^{2}=0.75$

$\begin{array}{llllll}0.068) & (0.089) & (0.054) & (0.079) & (0.028)\end{array}$

$\begin{array}{lllll}-1.93 & 1.42 & 4.52 & 8.28 & 9.01\end{array}$

$\mathrm{LP}=0.20 * \mathrm{KA}+0.17 * \mathrm{KD}-0.20 * \mathrm{PE}+0.044^{*} \mathrm{KP}+0.66 * \mathrm{KC}$,

Errorvar $=0.30, \mathrm{R}^{2}=0.70$
(0.075)
$(0.077)$
(0.062)

Where:

KA: Inpatients Satisfaction

KD: Doctor's Performance

PE: Treatment

KP: Nurse Performance

KC: Inpatients Trust

LP: Inpatient Loyalty

(Source: Appendix Output Lisrel 8.80)

Based on the structural equation 4.1, can be seen the magnitude of the path coefficient (loading factor) variable performance of physicians to inpatient satisfaction is equal to -0.13 , the magnitude of treatment variable loading factor to inpatient satisfaction is equal to 0.13 , the magnitude of the performance variable loading factor nurses to inpatient satisfaction is 0.25 and the magnitude of the loading factor variable inpatient confidence in inpatient satisfaction is 0.66 .

Based on structural equation 4.2, it can be seen the path coefficient (loading factor) variable performance of doctors on inpatient loyalty is 0.16 , the magnitude of treatment variable loading factor on inpatient loyalty is 0.20 , the magnitude of the performance variable loading factor nurses on inpatient loyalty is 0.043 , and the size of the loading factor variable inpatient confidence in inpatient loyalty is 0.66 and the magnitude of the variable loading factor inpatient satisfaction with inpatient loyalty is 0.20 .

\section{The Results of Testing the Hypothesis are as Follows}

\section{H1: There is an Influence of Doctor Performance on Inpatient Satisfaction}

The first hypothesis (H1) states that there is an effect of the doctor's performance on the satisfaction of hospitalized patients. Based on the test results obtained the estimated value of the doctor's performance variable is -0.13 and the Tstat value is $-1.93<$ T table 1.97 , meaning that the doctor's performance is influential but not significant to patient satisfaction.

The results of testing this hypothesis indicate that the doctor's performance is measured by the attitudes and behavior of doctors when conducting routine checks, the accuracy of the doctor examining the patient, the 
seriousness of the doctor in handling the patient's disease, the doctor's explanation of the treatment to be carried out and the doctor's response to the patient's complaints have no significant effect on satisfaction inpatients in international hospitals in Jakarta, Tangerang and Bekasi.

Batbaatar et al (2017) conducted research on patient satisfaction studies and obtained different results regarding patient satisfaction. The factors of doctors and nurses are two main things in determining patient satisfaction. In this study stated that the satisfaction of the doctor's performance is more due to affective behavior than competence. Affective behavior is meant by friendliness, sincerity, attention, sympathy, empathy, kindness, courtesy to patients or family and friends (courtesy to patients and family or friends). ) and respect for patient choices (respect for patient preferences).Patient satisfaction is more related to how doctors interact with patients than what doctors do to patients and (Van, D.A., and Dulewicz, V., 2014). Zineldin (2015) states that patients relate more to their satisfaction with nurses 'performance than doctors' performance.

Yipeng et al. (2016) writes that there are differences in factors that influence the satisfaction of outpatients and inpatients. The strongest determinant of outpatient satisfaction is the doctor's communication about the treatment regimen, followed by the level of trust in the doctor and the severity of the disease. While the determinants of inpatient satisfaction include satisfaction with the environment and satisfaction with medical quality.

This is important to get attention from hospitals in general and doctors as medical personnel in particular, who emphasize competence more than its affective behavior. Doctors or hospitals that are the place where doctors practice, need to emphasize the affective behavior of their doctors to further improve patient satisfaction. This becomes more meaningful to hospitalized patients compared with outpatients, because in hospitalized patients, doctors will often find patients to check the development of their patients' health.

\section{H2: There is an Influence of Treatment on Inpatient Satisfaction}

The second hypothesis $(\mathrm{H} 2)$ states that there is a treatment effect on inpatient satisfaction. Based on the test results obtained the estimated value of the treatment variable is 0.13 and the Tstat value is $1.42<\mathrm{T}$ table 1.97, meaning that treatment is influential but not significant to patient satisfaction.

The results of testing this hypothesis indicate that treatment as measured by the efficacy of medicines given by doctors, the side effects that occur and the price of drugs given as well as the completeness of medical equipment, medical equipment technology used and the costs for the use of tools have no significant effect on patient satisfaction. stays in international hospitals in Jakarta, Tangerang and Bekasi.

The results of testing this hypothesis are not in line with the results of research conducted by Chahal and Mehta (2013) which states that treatment has a significant effect on patient satisfaction. The presence of insignificant influence of treatment as measured by the price of the drug and the cost of the use of the tool can occur because patients - patients who use insurance facilities both BPJS and non BPJS.

\section{H3: There is an Influence of Nurse Performance on Inpatient Satisfaction}

The third hypothesis (H3) states that there is an effect of nurses' performance on inpatient satisfaction. Based on the test results obtained the estimated value of the nurse performance variable is 0.25 , meaning that the higher the perception of nurse performance, the higher the perception of patient satisfaction. This result is in accordance with the hypothesis proposed in this study, therefore the significance test is resumed. The test results show the Tstat value is $4.52>\mathrm{T}$ table 1.97 then null hypothesis is rejected. It was concluded that the performance of nurses had a significant and significant effect on patient satisfaction.

The results of testing this hypothesis indicate that the performance of nurses as measured by regularity of nurse services every day, the seriousness of nurses serve the needs of patients, personal assistance, such as bathing and feeding, nurses 'attitudes toward family and patient visitors, nurses' skills in serving such as injecting, drug 
administration and explanation of how to drink it, help nurses to sit, stand and walk, nurse explanation for the actions to be taken, and nurses' response to patient complaints have a significant effect on the satisfaction of inpatients in international hospitals in Jakarta, Tangerang and Bekasi. The indicators that reflect the most are the seriousness of doctors in handling patient diseases.

The results of testing this hypothesis are in line with the research conducted by Zineldin (2015), which states that patients are more connected to the satisfaction of the nurse's performance than the doctor's performance. Likewise with the study of Batbaatar et al (2017), where the factors of doctors and nurses are the two main things in determining patient satisfaction.

\section{H4: There is an Influence of Inpatient Trust on Inpatient Satisfaction}

The fourth hypothesis (H4) states that there is an effect of inpatient trust on satisfaction of inpatients. Based on the test results obtained the estimated value of the patient's trust variable of 0.66 , meaning that the higher the perception of inpatient trust, the higher the perception of satisfaction of inpatients. This result is in accordance with the hypothesis proposed in this study, therefore the significance test is resumed. The test results show the Tstat value is 8.28> T table 1.97 then null hypothesis is rejected. It was concluded that there was a significant effect of inpatient trust on the satisfaction of inpatients. The trust of inpatients shows a very large influence on the satisfaction of inpatients, which is $66 \%$.

The results of testing this hypothesis indicate that inpatient confidence as measured by the belief that the disease will be handled as well as possible, the belief that the communication received is very credible, trust in the consistency of hospital services, shows the ability of doctors to provide diagnosis and treatment, indicating that the risk has been taken into account in the decision, following the rules in conveying information and believing doctors will maintain medical confidentiality has a significant effect on the satisfaction of inpatients in international hospitals in Jakarta, Tangerang and Bekasi. The indicator that most reflects is the belief that the communication received is very credible.

The results of testing this hypothesis are in line with the results of research conducted by Baidya et al. (2014), Chang et al (2013), Tang (2012), Van and Dulewicz (2014), Van and Dulewicz (2015).

By looking at the high influence of inpatient trust on inpatient satisfaction, this patient's trust is very important to be considered by doctors and international hospital management in Jakarta, Bekasi and Tangerang.

\section{H5: There is an Influence of Doctor Performance on Inpatient Loyalty}

The fifth hypothesis (H5) states that there is an influence of the doctor's performance on the loyalty of inpatients. Based on the test results obtained the estimated value of the doctor's performance variable is 0.16 , meaning that the higher the perception of the doctor's performance, the higher the perception of inpatient loyalty. This result is in accordance with the hypothesis proposed in this study, therefore the significance test is resumed. The test results show the Tstat value is 2.15> T table 1.97 then null hypothesis is rejected. It was concluded that there was a significant effect of physician's performance on inpatient loyalty.

The results of testing this hypothesis indicate that the doctor's performance is measured by the attitudes and behavior of doctors when conducting routine checks, the accuracy of the doctor examining the patient, the seriousness of the doctor in handling the patient's disease, the doctor's explanation of the treatment to be carried out and the doctor's response to the patient's complaints have a significant effect on patient loyalty hospitalization in international hospitals in Jakarta, Tangerang and Bekasi. The indicators that reflect the most are the seriousness of doctors in handling patient diseases.

The results of testing this hypothesis are in line with the results of research conducted by Chahal and Mehta (2013), Van and Dulewicz (2015). 
The results of testing this hypothesis need to be considered by doctors and hospital managers with international standards to obtain inpatient loyalty. Baatbatar et al (2017) states that patients will recommend doctors to others due to affective behavior rather than competence. It is important for doctors in international hospitals to maintain and improve their affective behavior towards patients, especially inpatients in international hospitals in Jakarta, Tangerang and Bekasi.

\section{H6: There is an Influence of Treatment on Inpatient Loyalty}

The sixth hypothesis (H6) states that there is a treatment effect on inpatient loyalty.Based on the test results obtained the estimated treatment value of -0.20 and the Tstat value of $-1.95<$ Ttable 1.97 , meaning that treatment is influential but not significant to patient loyalty.

\section{H7: There is an Influenceof Nurse Performance on Inpatient Loyalty}

The seventh hypothesis (H7) states that there is an effect of nurses' performance on inpatient loyalty. Based on the test results obtained the estimated value of the nurse performance variable is 0.043 , meaning that the higher the perception of nurse performance, the higher the perception of patient loyalty. This result is in accordance with the hypothesis proposed in this study, therefore the significance test is resumed. The test results show that the Tstat value is $0.062<$ T table 1.97 then the null hypothesis fails to be rejected. It was concluded that the effect of nurses' performance on inpatient loyalty was not significant.

\section{H8: There is an Influence of Inpatient Trust on Inpatient Loyalty}

The eighth hypothesis (H8) states that there is an effect of inpatient trust on inpatient loyalty. Based on the test results obtained the estimated value of the patient's trust variable is 0.66 , meaning that the higher the perception of inpatient trust is the higher the perception of inpatient loyalty. This result is in accordance with the hypothesis proposed in this study, therefore the significance test is resumed. The test results show the Tstat value is 6.42> T table 1.97 then null hypothesis is rejected. It was concluded that there was a significant effect of inpatient trust on inpatient loyalty. The trust of inpatients shows a very large influence on the loyalty of inpatients, which is $66 \%$.

The results of testing this hypothesis indicate that inpatient confidence as measured by the belief that the disease will be handled as well as possible, the belief that the communication received is very credible, trust in the consistency of hospital services, shows the ability of doctors to provide diagnosis and treatment, indicating that the risk has been taken into account in the decision, following the rules in conveying information and believing doctors will maintain medical confidentiality has a significant effect on the loyalty of inpatients in international hospitals in Jakarta, Tangerang and Bekasi. The indicator that most reflects is the belief that the communication received is very credible.

The results of testing this hypothesis are in line with the results of research conducted by Ramli and Sjahruddin (2015), Sumaedi et al. (2015) and Yarmen et al (2016).

The results of testing this hypothesis are important to be considered by hospital management, in order to obtain loyalty from inpatients in international hospitals. With the value of the influence of inpatient trust of $66 \%$ on patient loyalty, obtaining and maintaining the trust of inpatients in international hospitals is very important. This loyal patient will be a good asset and spokesperson for international hospitals in maintaining and increasing the trust of patients and prospective inpatients.

\section{H9: There is an Influenceof Inpatient Satisfaction on Inpatient Loyalty}

The ninth hypothesis (H9) states that there is an effect of inpatient satisfaction on inpatient loyalty. Based on the test results obtained the estimated value of the patient satisfaction variable is 0.20 , meaning that the higher the perception of patient satisfaction, the higher the perception of patient loyalty. This result is in accordance 
with the hypothesis proposed in this study, therefore the significance test is resumed. The test results show the Tstat value is $2.72>\mathrm{T}$ table 1.97 then null hypothesis is rejected. It was concluded that there was a significant effect of patient satisfaction on patient loyalty.

The results of testing this hypothesis indicate that inpatient satisfaction is measured by trust in the consistency of hospital services received, services of other medical support staff, such as laboratories, physiotherapy, administrative services, cleaning services and tidiness of care rooms and patient satisfaction with hospital services. in total significant effect on inpatient loyalty in international hospitals in Jakarta, Tangerang and Bekasi. As for the indicators that most reflect is patient satisfaction with total hospital services.

The results of testing this hypothesis are in line with the results of research conducted by Chahal and Mehta (2013), Ramli and Sjahruddin (2015) and Van and Dulewicz (2015). The hospital management must be able to maintain and increase the satisfaction of inpatients so that the loyalty of inpatients in international hospitals in Jakarta, Bekasi and Tangerang increases.

\section{CONCLUSION}

The main finding of this study is that patient satisfaction is influenced by patient trust and nurse performance. The doctor's performance and treatment have an effect but not significant on patient satisfaction. The trust of patients influences and significantly affects patient satisfaction, with a value of 0.66 . The indicators that reflect are the belief that the communication received is very credible. The performance of nurses has a significant and significant effect on patient satisfaction, with a value of 0.25 . The indicators that reflect are nurses' attitudes toward patients.

While patient loyalty is most strongly influenced by patient trust. Patient loyalty is also influenced by patient satisfaction and doctor's performance. Patient trust has a significant and significant effect on patient loyalty, with a value of 0.66 . The indicators that reflect are the belief that the communication received is very credible. Patient satisfaction has a significant effect on patient loyalty, with a value of 0.20 . The indicators that reflect the patient's satisfaction with hospital services in total. The performance of doctors influences and significantly affects patient loyalty, with a value of 0.16 . The indicators that reflect are the seriousness of the doctor in handling the patient's disease. Treatment and performance of nurses have an effect but not significant on patient loyalty.

\section{Theoretical and Managerial Implications}

The theoretical implications of this study are found patient loyalty models by involving constructors of nurse performance, patient trust and patient satisfaction that can affect patient loyalty. This model can provide an alternative that enriches the literature on patient loyalty, especially inpatients. The managerial implications of this study are that the satisfaction of inpatients in an international hospital will increase if the nurse's performance and patient trust are increased. Likewise, the loyalty of inpatients in international hospitals will increase if the doctor's performance, patient trust and inpatient satisfaction increase. A very dominant factor in determining patient satisfaction and patient loyalty is patient trust. This means that the hospital management needs to be very concerned about patient trust.

\section{Research Limitations and Recommendations for Further Research}

This study is limited to factors that influence inpatient satisfaction and loyalty in terms of physician performance, treatment, nurse performance and inpatient trust. There are other factors that influence the satisfaction and loyalty of inpatients, in addition to the variables in this study, such as the image of the hospital and patient's disease. These things need to be considered This research was conducted at international hospitals without differentiating private or government management and hospital classes, so that further research is expected to be carried out with more focused research objects. Research can also be carried out on the characteristics 
of patients who are more homogeneous, both in terms of demographics such as age, gender, education, marital status, income level and in terms of funding for care and inpatient classes as well as the causes of hospitalization. The results of research on inpatient loyalty can also be applied to outpatients and emergency patients.

\section{REFERENCES}

Arman Anwar (2016), MampukahSektorKesehatan Indonesia Berkompetisidalam Ajang Masyarakat Ekonomi ASEAN? Seminar tentang "Peluangdan Tantangan Tenaga Medis Indonesia di Era PasarBebas ASEAN", Diselenggarakanoleh Pusat Studi ASEAN dengan Pemda Kabupaten Maluku Tengah di Masohi, Kamis 28 Januari 2016.

Baidya, M., Gopichandran, V., \&Kosalram, K. (2014). Patient-physician trust among adults of rural tamilnadu: A community-based survey.Journal of Postgraduate Medicine, 60(1), 21-6.

Batbaatar, E., Dorjdagva, J., Luvsannyam, A., Savino, M. M., \&Amenta, P. (2017). Determinants of patient satisfaction: A systematic review. Perspectives in Public Health, 137(2), 89-101.

Bharamanaikar, S. R., \&Kadadi, S. V. (2016). Role of the medical practitioners emotional intelligence on patient satisfaction. International Journal of Marketing \& Business Communication, 5(1).

Chahal H dan Mehta S (2013), Modeling patient satisfaction construct in the Indian health Patient satisfaction construct care context.

Chang, C., Chen, S., \& Lan, Y. (2013). Service quality, trust, and patient satisfaction in interpersonal-based medical service encounters. BMC Health Services Research, 13, 22.

Crosier M., Scott B.S.J.,Steinfeld B.B.A. (2012), Improving Satisfaction in Patients Receiving Mental Health Care: A Case Study. The Journal of Behavioral Health Services \& Research 39:1 January 2012, pp 42-54.

DewanJaminan Sosial Nasional. PetaJalan Jaminan Kesehatan Nasional 2012-2019. Jakarta: DJSN; 2012.

Direktorat Jendral Kerjasama ASEAN Departemen Luar Negeri RI 2009. Cetak Biru Komunitas

Glenngard, A.H. (2012), Is patient satisfaction in primary care dependent on structural and organizational characteristics among providers? Findings based on data from the national patient survey in Sweden. Health Economics, Policy and Law (2013), 8, 317-333 \& Cambridge University Press 2012, pp 317-333. First published online 8 October 2012

Hawthorne, G., Sansoni, J., Hayes, L., Marosszeky, N., \& Sansoni, E. (2014). Measuring patient satisfaction with health care treatment using the short assessment of patient satisfaction measure delivered superior and robust satisfaction estimates. Journal of Clinical Epidemiology, 67(5), 527-37.

Kessler, D. P., \& Mylod, D. (2011). Does patient satisfaction affect patient loyalty?International Journal of Health Care Quality Assurance, 24(4), 266-73.

Khariza, H. A. (2015). Program Jaminan KesehatanNasional: Studi Deskriptiftentang Faktor-Faktor yang Dapat Mempengaruhi Keberhasilan Implementasi Program Jaminan Kesehatan Nasional Di Rumah Sakitjiwa Menur Surabaya. Kebijakandan Manajemen Publik, 3 (1), 1-7.

Kian, T. P., \& Heng, T. K. (2015).An exploratory study on the factors that influence patient satisfaction and its impact on patient loyalty. International Journal of Innovation, Management and Technology, 6(3), 180-185.

Lei, P., \& Jolibert, A. (2012). A three-model comparison of the relationship between quality, satisfaction and loyalty: An empirical study of the chinese healthcare system. BMC Health Services Research, 12, 436.

Lien, C., Wu, J., Chen, Y., \& Wang, C. (2014). Trust transfer and the effect of service quality on trust in the healthcare industry. Managing Service Quality, 24(4), 399-416.

American Research Journal of Business and Management

Page 16 
Satisfaction and Loyalty of Inpatients in International Hospital at Jakarta, Tangerang and Bekasi

Lonial S., Raju P.S. (2014), Impact of service attributes on customer satisfaction and loyalty in a healthcare context.

Moreira, A. C., \& Silva, P. M. (2015). The trust-commitment challenge in service quality-loyalty relationships. International Journal of Health Care Quality Assurance 28(3), 253-266.

Naidu, A. (2009). Factors affecting patient satisfaction and healthcare quality. International Journal of Health Care Quality Assurance, 22(4), 366-81.

Naik, J. R., Anand, B., \& Bashir, I. (2015). An empirical investigation to determine patient satisfaction factors at tertiary care hospitals in india. International Journal of Quality and Service Sciences, 7(1), 2-16.

Panchapakesan, P., Sai, L. P., \& Rajendran, C. (2015). Customer satisfaction in indian hospitals: Moderators and mediators. The Quality Management Journal, 22(1), 10-29,4.

Puja, I.G.A.W. (2015), ASEAN 2025: Kewaspadaan, Determinandan Optimisme. Masyarakat ASEAN Edisi 10, Desember 2015

Ramli, A. H., \& Sjahruddin, H. (2015). Building patient loyalty in healthcare services. International Review of Management and Business Research, 4(2), 391-401.

Rowe, R., \& Calnan, M. (2006). Trust relations in health care: Developing a theoretical framework for the "new" NHS. Journal of Health Organization and Management, 20(5), 376-96.

Saputra M., Marlinae L., Rahman F., Rosadi D. (2015), Program Jaminan Kesehatan Nasionaldari Aspek Sumber Daya Manusiapelaksana Pelayanan Kesehatan. Jurnal Kesehatan Masyarakat Kemas 11 (1) (2015) 32-42

Sekaran, U danBougie, R. (2013), Research Methods for Business: A skill Building Approach. Sixth edition, John Willey \& Son Ltd, West Sussex, United kingdom.

Shirley E., Josephson G., Sanders J. (2016), Fundamental of Patient Satisfaction Measurement, Physician Leadership Journal January 2016, pp 12-17.

Simonds, V. W., Goins, R. T., Krantz, E. M., \& Garroutte, E. M. (2014). Cultural identity and patient trust among older americanindians.Journal of General Internal Medicine, 29(3), 500-6.

Soares, A. M., \& Farhangmehr, M. (2015). Understanding patient satisfaction in a hospital emergency department. International Review on Public and Non - Profit Marketing, 12(1), 1-15.

Sumaedi, S., Bakti, I. G., Rakhmawati, T., Astrini, N. J., Yarmen, M., \&Widianti, T. (2015).Patient loyalty model. Leadership in Health Services, 28(3), 245-258.

Sumaedi, S., YudaBakti, ,I.Gede Mahatma, Rakhmawati, T., Astrini, N. J., Widianti, T., \&Yarmen, M. (2016). Indonesian public healthcare service institution's patient satisfaction barometer (IPHSI-PSB). International Journal of Productivity and Performance Management, 65(1), 25-41.

Tang, L. (2012). The influences of patient's satisfaction with medical service delivery, assessment of medical service, and trust in health delivery system on patient's life satisfaction in china.Health and Quality of Life Outcomes, 10, 111.

Thom, D. H., Hall, M. A., \&Pawlson, L. G. (2004). Measuring patients' trust in physicians when assessing quality of care. Health Affairs, 23(4), 124-32.

UU RI.(2009). Undang-undangRepublikIndonesia Nomor 44 tentangRumahSakit[Internet]. Tersediadalam<www. depkes.go.id> [Diakses 15 Oktober 2016].

Van, D. A., \& Dulewicz, V. (2014). Patient satisfaction and GP trustworthiness, practice orientation and 
Satisfaction and Loyalty of Inpatients in International Hospital at Jakarta, Tangerang and Bekasi

performance.Journal of Health Organization and Management, 28(4), 532-47.

Van, D. A., \& Dulewicz, V. (2015). Doctors' trustworthiness, practice orientation, performance and patient satisfaction. International Journal of Health Care Quality Assurance, 28(1), 82-95.

Van, D. B., Rustagi, K., Gray, T., Halford, M., Ziemkiewicz, E., \& Shreve, J. (2011). The \$17.1 billion problem: The annual cost of measurable medical errors. Health Affairs, 30(4), 596-603.

Yarmen, M., Sumaedi, S., Bakti, I. G., Rakhmawati, T., Astrini, N. J., \&Widianti, T. (2016).Investigating patient loyalty. International Journal of Quality and Service Sciences, 8(2), 179-196.

Yipeng, LV ., Xue, C., Ge, Y., Ye, F., Liu, X., Liu, Y., \& Zhang, L. (2016). Analysis of factors influencing inpatient and outpatient satisfaction with the chinese military health service.PLoS One, 11(3).

Zineldin, M. (2015).Determinants of patient safety, satisfaction and trust. Clinical Governance, 20(2), 82-90.

Citation: Kartono, Farida Jasfar, HamdyHady. "Satisfaction and Loyalty of Inpatients in International Hospital at Jakarta, Tangerang and Bekasi". American Research Journal of Business and Management. 2018; 4(1): 1-18.

Copyright (C) 2018 Kartono, Farida Jasfar, HamdyHady. This is an open access article distributed under the Creative Commons Attribution License, which permits unrestricted use, distribution, and reproduction in any medium, provided the original work is properly cited. 